\title{
PENGUKURAN PRODUKTIVITAS MESIN TETAS TELUR DENGAN METODE OVERALL EQUIPMENT EFFECTIVENESS (OEE) DI PT. MALINDO FEEDMILL. Tbk.
}

\author{
Susanti Sundari, Hadi Wahyono
}

\author{
Program Studi Teknik Industri Fakultas Teknik \\ Universitas Tulang Bawang Lampung
}

\begin{abstract}
This study discusses the measurement of egg hatching machine productivity at PT. Malindo Feedmill.Tbk, in Peninjauan, Bumiagung Village, Tegineneng District, Pesawaran Regency. The purpose of this study was to determine how much productivity from the hatching results of broiler chicken eggs with Petersime and Chickmaster hatching machines. The method used in this study is to use the OEE (Overall Equipment Effectiveness) method. Besed on the best results obtained on the Petersime type hatching machine than the Chickmaster in percentage calculation Availability Rate (91,13\%), Performance Rate (11,37\%), and Rate of Quality (99,53\%). So that the average value of overall equipment effectiveness or effectiveness of the use of manufactured machines of $(O E E=97,53 \%)$. The conclusion of this study is the OEE value achieved by the Petersime type hatching machine has met the set standards for the effectiveness of an equipment of $85 \%$ (JIPM) whereas on the Chickmaster type hatching machine does not meet the OEE standard value because it is still below 85\%, in the analysis of Six Big Losses it is known that the engine breakdown factor (Break Down Losses) is the dominant factor as the cause of production equipment not operating normally either on the Petersime type hatching machine and Chickmaster.
\end{abstract}

Keywords: Productivity, OEE, Hatching Machine, Petersime, Chickmaster

\section{Pendahuluan}

Agar perusahaan terus maju dan berkembang, mutlak perlu peningkatan produktivitas perusahaan dalam mencapai tujuannya. Bagi perusahaan penetasan telur menjadi anak ayam, dimana perusahaan berperan sebagai penyedia anak ayam yang dalam peternakan merupakan inti kegiatan atau di dalam pabrik di umpamakan sebagai mesinnya. Menetaskan telur ayam, berarti meliputi kegiatan mengeramkan telur ayam hingga telur ayam tersebut menetas. Penetasan yang di lakukan PT. Malindo merupakan penetasan buatan, rekayasa penetasan telur yang sudah tidak menggunakan induk ayam betina tetapi menggunakan alat mesin tetas telur, menggunakan 2 jenis mesin tetas jenis Chickmaster dan Petersime. Data hasil panen DOC pada Tabel 1 menunjukan hasil panen lebih bagus menggunakan mesin Petersime di bandingkan menggunakan mesin jenis Chickmaster. Dengan melihat haltersebut perlu diteliti lebih jauh mengenai peningkatan produktivitas dan kualitas anak ayam yang di hasilkan dari kedua mesin tetas telur. Dan tujuan dari 
penelitian ini untuk mengetahui berapa besar produktivitas dari hasil penetasan telur ayam potong dengan mesin tetas (Overall Equipment Effectiveness).

Tabel1. Data Hasil Panen DOC

Mesin Petersime

\begin{tabular}{cccccc}
\hline House & Fertile & Diss & Cull & DOC B & DOC A \\
\hline 1 & 10.508 & 254 & 31 & 26 & 10.197 \\
2 & 10.548 & 240 & 36 & 31 & 10.241 \\
3 & 12.981 & 291 & 28 & 36 & 12.626 \\
4 & 14.134 & 162 & 27 & 32 & 13.913 \\
5 & 15.394 & 196 & 35 & 21 & 15.142 \\
6 & 15.376 & 212 & 39 & 39 & 15.086 \\
9 & 8.152 & 202 & 40 & 22 & 7.888 \\
10 & 7.007 & 219 & 35 & 40 & 6.713 \\
11 & 8.188 & 227 & 37 & 41 & 7.883 \\
12 & 10.569 & 312 & 40 & 32 & 10.185 \\
\hline Jumlah & 112.857 & 2315 & 348 & 320 & 109.874 \\
\hline \multicolumn{6}{c}{ Mesin Chickmaster } \\
\hline \multicolumn{7}{c}{ Ciss } & Cull & DOC B & DOC A \\
\hline House & Fertile & Diss & \\
\hline 1 & 10.508 & 513 & 71 & 65 & 9.859 \\
2 & 10.548 & 497 & 65 & 53 & 9.933 \\
3 & 12.981 & 501 & 49 & 59 & 12.372 \\
4 & 14.134 & 352 & 48 & 52 & 13.682 \\
5 & 15.394 & 394 & 61 & 48 & 14.891 \\
6 & 15.376 & 397 & 79 & 67 & 14.833 \\
9 & 8.152 & 403 & 56 & 43 & 7.650 \\
10 & 7.007 & 379 & 75 & 74 & 6.479 \\
11 & 8.188 & 390 & 59 & 63 & 7.676 \\
12 & 10.569 & 496 & 79 & 69 & 9.925 \\
\hline Jumblah & 112.857 & 4.322 & 642 & 593 & 107.300 \\
\hline Sumber: Data perus ahaanbulan April2019 & &
\end{tabular}

Keterangan:

1. Fertile: jumlah telur yang siap untuk di tetaskan

2. Diss: telur yang tidak menetas

3. Cull: ayam DOC yang cacat

4. DOC B: tipe ayam yang kurang baik untuk di jual

5. DOC A: tipe ayam yang bagus yang siap untuk di jual

\section{Tinjauan Pustaka}

\section{Proses Penetasan}

Penetasan merupakan proses perkembangan embrio di dalam telur sampai telur pecah menghasilkan anak ayam. Penetasan dapat dilakukan secara alami oleh induk ayam atau secara buatan menggunakan mesin tetas. Telur yang digunakan adalah telur tetas, yang
Petersime dan Chickmaster, dengan menggunakan metode OEE

6. DOC :Day Old Chicken atau ayam umur sehari. merupakan telur fertil atau telur yang telah dibuahi oleh sperma, dihasilkan dari peternakan ayam pembibit, bukan dari peternakan ayam petelur komersil.

Pada prinsipnya penetasan telur dengan mesin tetas adalah mengkondisikan telur sama seperti telur yang dierami oleh induknya. Baik itu suhu, kelembaban dan juga posisi telur. Dalam proses penetasan dengan 
menggunakan mesin tetas memiliki kelebihan di banding dengan penetasan secara alami, yaitu dapat dilakukan sewaktu-waktu, dapat dilakukan dengan jumlah telur yang banyak, menghasilkan anak dalam jumlah banyak dalam waktu bersamaan, dapat dilakukan pengawasan dan seleksi pada telur.

\section{Mesin Tetas Jenis Petersime}

Petersime adalah sebuah inovasi alat atau mesin rekayasa penetasan guna memudahkan proses inkubasi pada usaha penetasan. Petersime merupakan inkubator asal Belgia yang diperkenalkan oleh $\mathrm{Mr}$ Petersime (1912). Seiring berjalannya waktu mesin tetas Petersime pun berkembang pesat dan menjadi andalan bagibanyak perusahaan penetasan di Indonesia hingga belahan dunia. Dalam dunia penetasan, inkubator Petersime ini terkenal handal, mudah, murah, dan mumpuni, sehingga banyak perusahaan penetasan di Indonesia mengimport dan mengaplikasikan mesin tetas ini. Mesin tetas Petersime memiliki berbagai tipe,mesin berukuran kurang lebih 5,5 x 3 x 1,5 (setter) dan 2,5 x3 x 1,5 (hatcher) dibangun secara berderet diatas lantai epoxy. Inkubator yang didesain dengan sangat apik ini merupakan mesin tetas berskala besar, dengan kuantitas hingga 115.200 butir telur dalam satu mesin dari 4.800 butir telur dalam satu trolly.

Selain memiliki desain yang simple, mesin Petersime juga memiliki daya tetas (hatchibility) yang cukup baik. Karena dirancang agar lebih mudah jika terjadi masalah (trouble) dan hal - hal yang dapat mempengaruhi kualitas telur tetas. Operasional program pada inkubator Petersime tergolong mudah dipahami, dipelajari dan juga mudah ketika melakukan setting program karena

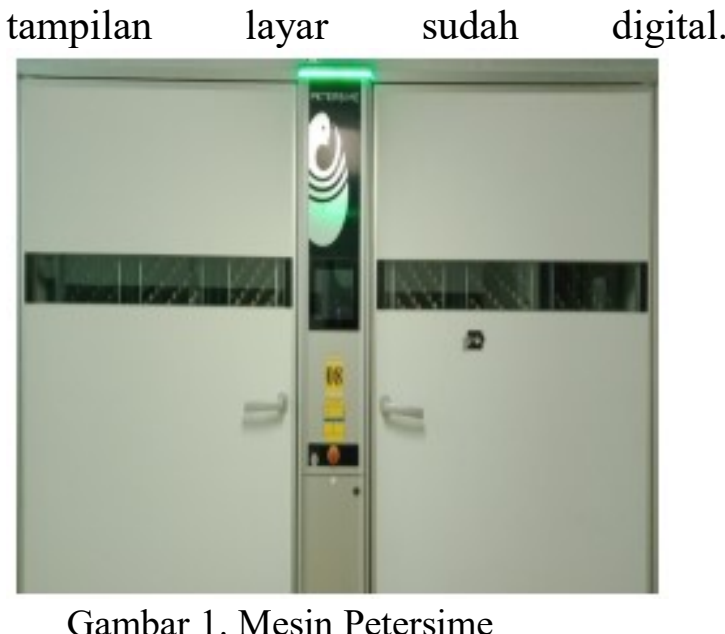

Sumber : Data Penelitian

\section{Mesin Tetas Jenis Chickmaster}

Mesin tetas chickmaster adalah sebuah mesin yang membantu proses penetasan telur yang berfungsi untuk menggantikan proses pengeraman yang dilakukan oleh indukan. Kesetabilan suhu dilakukan dengan alat pengatur suhu yang telah melekat didalam mesin tetas chickmaster kita kenal sebagai thermostat. Untuk itu banyak perusahaan memproduksi mesin penetas telur salah satunya mesin penetas telur merk chickmaster. Mesin penetas telur merk chickmaster adalah salah satu mesin mengutamakan mesin yang hemat daya listrik dan di lengkapi dengan jendela ventilasi pada mesin yang berfungsi untuk menyediakan oksigen dan mengeluarkan $\mathrm{CO} 2$ hasil metabolisme. Mengatur posisi telur turning yang menggunakan dynamo atau motor penggerak kemudian diteruskan menggunakan gearbook untuk memutarkan troly pad arak telur, Kapasitas mesin chickmaster 115.200 butir telur ayam, layar monitor pada mesin chickmaster masih belum digital. 


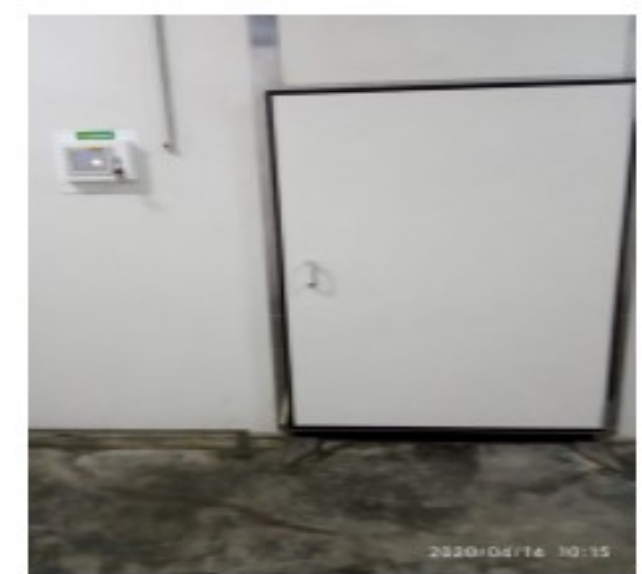

Gambar 2. Mesin Chickmaster Sumber : Data Penelitian

\section{Konsep Produktivitas}

Produktivitas berasal dari kata "produktif" artinya sesuatu yang mengandung potensi untuk digali, sehingga produktivitas dapatlah dikatakan sesuatu proses kegiatan yang struktur guna menggali potensi yang ada dalam sebuah komoditi atau objek. Filosofi produktivitas sebenarnya dapat mengandung arti keinginan dan usaha dari setiap manusia (individu atau kelompok) untuk selalu meningkatkan mutu kehidupannya (Muhammad Kholil, 2014)

Produktivitas sangat berkaitan erat dengan keberhasilan dan pemberdayagunaan serta kemampuan sebuah perusahaan jika di ukur pada tingkat mikro sedangkan untuk tingkat makro produktivitas lebih sering digunakan untuk perbandingan kekuatan ekonomi suatu bangsa. Secara umum produktivitas diartikan sebagai hubungan antara hasil nyata maupun fisik (barangbarang atau jasa) dengan masukan yang sebenarnya. Suatu perbandingan antara hasil keluaran dan masukan. Masukkan sering di batasi dengan masukan tenaga kerja, sedangkan keluaran diukur dalam kesatuan fisik bentuk dan nilai (Siagian, 2003).

Dalam pengertian yang lebih luas, produktivitas merupakan hubungan antara output dengan input yang digunakan untuk menghasilkan output tersebut. Atau dengan kata lain produktivitas adalah rasio dari beberapa output tersebut dengan beberapa input. Produktivitas dengan produksi merupakan dua konsep yang sangat berbeda, yang terkadang sering membingungkan dalam pengertiannya. Unsur produktivitas salah satunya adalah kualitas. Pada dasarnya produktivitas dapat diukur dari segi kualitas yang merupakan penambahan pada proses input.

\section{Pengertian OEE}

Pengertian Overall Equipment Effectiveness (OEE) adalah suatu perhitungan yang dilakukan untuk mengetahui sejauh mana tingkat keefektifan suatu mesin atau peralatan yang ada. OEE merupakan salah satu metode yang ada dalam Total Produktive Mentenance (TPM). Umumnya, OEE digunakan sebagai indikator performasi suatu mesin atau peralatan. Overall Equipment Effectiveness atau efektivitas peralatan secara keseluruhan merupakan istilah yang diciptakan oleh Seiichi Nakajima pada tahun 1960 untuk mengevaluasi seberapa efektif operasi manufaktur digunakan. Hal ini didasarkan pada cara berpikir Harrington Emerson mengenai efisiensi tenaga kerja. Tujuan OEE (Overall Equipment Effectiveness) yaitu sebagai alat ukur performa suatu sistem maintenance, dengan menggunakan metode ini maka bisa diketahui ketersediaan mesin atau peralatan, efesiensi produksi dan kualitas output mesin atau peralatan.

Perhitungan yang digunakan untuk menentukan tingkat produktivitas dan efektivitas peralatan. Rumus OEE (Overall Equipment Effectiveness): OEE (\%) = Availability rate $(\%) \times$ Performance rate $(\%) \times$ Rate of quality (\%). Berdasarkan penghargaan yang pernah diberikan JIPM (Japan Institute of Plant Maintenance) kondisi ideal OEE yaitu:

1. Availability rate $>90 \%$

2. Performance rate $>95 \%$

3. Rate of quality $>99 \%$

Sehingga OEE yang ideal yaitu: $0,90 \mathrm{x}$ $0,95 \times 0,99=85 \%$. Terdapat 3 (tiga) elemen produktivitas dan efektivitas 
peralatan yang bisa diukur yaitu Availability rate, Performance rate, Rate of quality.

\section{Availability rate}

Availability rate adalah tingkat efektivitas beroperasinya suatu mesin atau peralatan. Availability rate merupakan perbandingan antara waktu operasi dan waktu persiapan. Parameter ini menentukan tingkat kesiapan alat yang ada dan bisa digunakan. Ketersediaan yang rendah mencerminkan pemeliharaan yang buruk, sehingga untuk melakukan perhitungan nilai Availability rate diperlukan operation time, loading time dan downtime. Rumus Availability rate yaitu:

$$
\begin{aligned}
& \text { Availability rate }=\frac{\text { operation time }}{\text { loading time }} \times 100 \% \\
& \text { Availability rate }=\frac{\text { Loading Time-down time }}{\text { Loading Time }} \times 100 \%
\end{aligned}
$$

Keterangan:

1.Operation time, yaitu hasil yang didapatkan dari pengurangan loading time dengan waktu downtime mesin.

Keterangan:

1. Ideal cycle time (waktu siklus ideal).

2. Processed amount (Jumlah produk yang diproses).

3. Operation time (waktu operasi mesin).

\section{Rate of Quality}

Rate of quality adalah rasio jumlah produk yang baik terhadap total produk yang diproses. Rate of quality menunjukkan produk yang bisa diterima per total produk yang dihasilkan,ini

\section{Metodologi Penelitian}

\section{Metode Pengumpulan Data}

Metode penelitian yang digunakan adalah penelitian deskriptif. Data-data yang dibutuhkan dalam penelitian ini antara lain:

\section{a. Data primer}

Data primer didapatkan melalui proses wawancara dengan karyawan.
2. Downtime mesin, yaitu waktu proses yang seharusnya digunakan mesin tapi karena adanya gangguan pada mesin/peralatan mengakibatkan tidak ada output yang dihasilkan. Downtime meliputi mesin berhenti beroperasi akibat kerusakan mesin atau peralatan, penggantian cetakan, pelaksanaan prosedur setup dan adjustment dan lain sebagainya.

3. Loading time yaitu waktu yang tersedia perhari atau perbulan dikurang dengan waktu downtime mesin direncanakan.

\section{Performance rate}

Performance rate adalah hasil perkalian dari operation speed rate dan net operation rate, atau rasio kuantitas produk yang dihasilkan dikalikan dengan waktu siklus idealnya terhadap waktu yang tersedia untuk melakukan proses produksi. Rumus Performance rate yaitu:

Performance rate $=\frac{\text { Processed amount } x \text { Ideal cycle time }}{\text { operation time }} \times 100 \%$

Ideal cycle time $=\frac{\text { Loading Time }}{\text { Processed amount }}$ memperhatikan dua faktor, diantaranya yaitu:

1. Processed amount (jumlah yang diproduksi).

2. Defect amount (jumlah produk yang cacat).

Rate of Quality product $=\frac{\text { Processed amount }- \text { Defect amount }}{\text { Processed amount }} \times 100 \%$

b. Data sekunder

Data sekunder didapatkan dari arsip dan dokumen di perusahaan pada periode Agustus 2018 sampai Agustus 2019 pada Tabel 2, 3 dan 4 sbb: 
Tabel 2. Data Downtime mesin Petersime dan Chickmaster

\begin{tabular}{lcc}
\hline \multicolumn{1}{c}{ Bulan } & $\begin{array}{c}\text { Downtime (menit) } \\
\text { Mesin Petersime }\end{array}$ & $\begin{array}{c}\text { Downtime (menit) } \\
\text { Mesin Chichmaster }\end{array}$ \\
\hline Agustus 2018 & 2890 & 3970 \\
September 2018 & 2780 & 3890 \\
Oktober 2018 & 2840 & 3087 \\
November 2018 & 2798 & 3563 \\
Desember 2018 & 2749 & 3254 \\
Januari 2019 & 2892 & 3765 \\
Februari 2019 & 2772 & 3678 \\
Maret 2019 & 2832 & 3099 \\
April 2019 & 2325 & 3987 \\
Mei 2019 & 2426 & 3980 \\
Juni 2019 & 2974 & 3876 \\
Juli 2019 & 2386 & 3211 \\
Agustus 2019 & 2325 & 3091 \\
\hline
\end{tabular}

Tabel 3. Data jam kerja mesin Petersime dan Chickmaster

\begin{tabular}{lcc}
\hline \multicolumn{1}{c}{ Bulan } & $\begin{array}{c}\text { Jam kerja (menit) } \\
\text { Mesin Petersime }\end{array}$ & $\begin{array}{c}\text { Jam kerja (menit) } \\
\text { Mesin Chichmaster } \\
\text { Agustus 2018 }\end{array}$ \\
September 2018 & 30320 & 30477 \\
Oktober 2018 & 30380 & 30459 \\
November 2018 & 30401 & 30481 \\
Desember 2018 & 30390 & 30498 \\
Januari 2019 & 30387 & 30489 \\
Februari 2019 & 30399 & 30495 \\
Maret 2019 & 30387 & 30481 \\
April 2019 & 30390 & 30499 \\
Mei 2019 & 30397 & 30465 \\
Juni 2019 & 30387 & 30475 \\
Juli 2019 & 30367 & 30456 \\
Agustus 2019 & 30409 & 30476 \\
\hline
\end{tabular}

Tabel 4. Jumlah produksi per mesin Petersime

\begin{tabular}{lcc}
\hline \multicolumn{1}{c}{ Bulan } & $\begin{array}{c}\text { produksi } \\
\text { Mesin Petersime (per } \\
\text { ekor) }\end{array}$ & $\begin{array}{c}\text { Defect permesin } \\
\text { Petersime (per ekor) }\end{array}$ \\
\hline Agustus 2018 & 94656 & \\
September 2018 & 94670 & 410 \\
Oktober 2018 & 94701 & 419 \\
November 2018 & 94727 & 427 \\
Desember 2018 & 94011 & 417 \\
Januari 2019 & 93971 & 451 \\
Februari 2019 & 93997 & 424 \\
Maret 2019 & 94000 & 432 \\
April 2019 & 93801 & 439 \\
Mei 2019 & 93891 & 443 \\
Juni 2019 & 94015 & 457 \\
Juli 2019 & 94062 & 448 \\
Agustus 2019 & 93914 & 437 \\
\hline
\end{tabular}

Tabel 5. Jumlah produksi per mesin Chickmaster

\begin{tabular}{lcc}
\hline \multicolumn{1}{c}{ Bulan } & $\begin{array}{c}\text { produksi } \\
\text { Mesin Chickmaster }\end{array}$ & $\begin{array}{c}\text { Defect permesin } \\
\text { Chickmaster }\end{array}$ \\
\hline Agustus 2018 & 93711 & 473 \\
September 2018 & 93799 & 462 \\
Oktober 2018 & 93617 & 481 \\
November 2018 & 94013 & 479 \\
Desember 2018 & 93711 & 497 \\
Januari 2019 & 93119 & 489 \\
Februari 2019 & 93123 & 499 \\
Maret 2019 & 93670 & 491 \\
April 2019 & 93511 & 483 \\
Mei 2019 & 93711 & 494 \\
Juni 2019 & 93816 & 509 \\
Juli 2019 & 93847 & 482 \\
Agustus 2019 & 93701 & 507 \\
\hline
\end{tabular}

\section{Pengolahan Data}

Langkah-langkah yang dilakukan pada tahap pengolahan data ini adalah:

I. Perhitungan Overall Equipment Effectiveness (OEE) besar efektivitas yang ada dalam pengoprasian mesin tersebut. Langkah perhitungan nilai OEE dilakukan antara lain adalah sebagai berikut:

a. Perhitungan nilai Availability Rate perhitungan ini bertujuan untuk mengetahui tingkat ketersediaan mesin beroperasi atau tingkat pemanfaatan peralatan produksi.

b. Perhitungan Performance Rate perhitungan ini untuk mengetahui tingkat efektivitas mesin dan peralatan pada saat kegiatan produksi.

c. Perhitungan nilai Rate of Quality perhitungan ini untuk menentukan keefektifan produksi berdasarkan kualitas produk yang dihasilkan.

d. Perhitungan nilai OEE sendiri berfungsi untuk mengetahui tingkat keefektifan dari mesin yang menjadi objek penelitian.

II. Perhitungan Six Big Losses tujuan dilakukan perhitungan Six Big Losses adalah untuk mengetahui losses mana yang menyebabkan nilai efektivitas mesin rendah.

\section{Diagram Alir Penelitian}




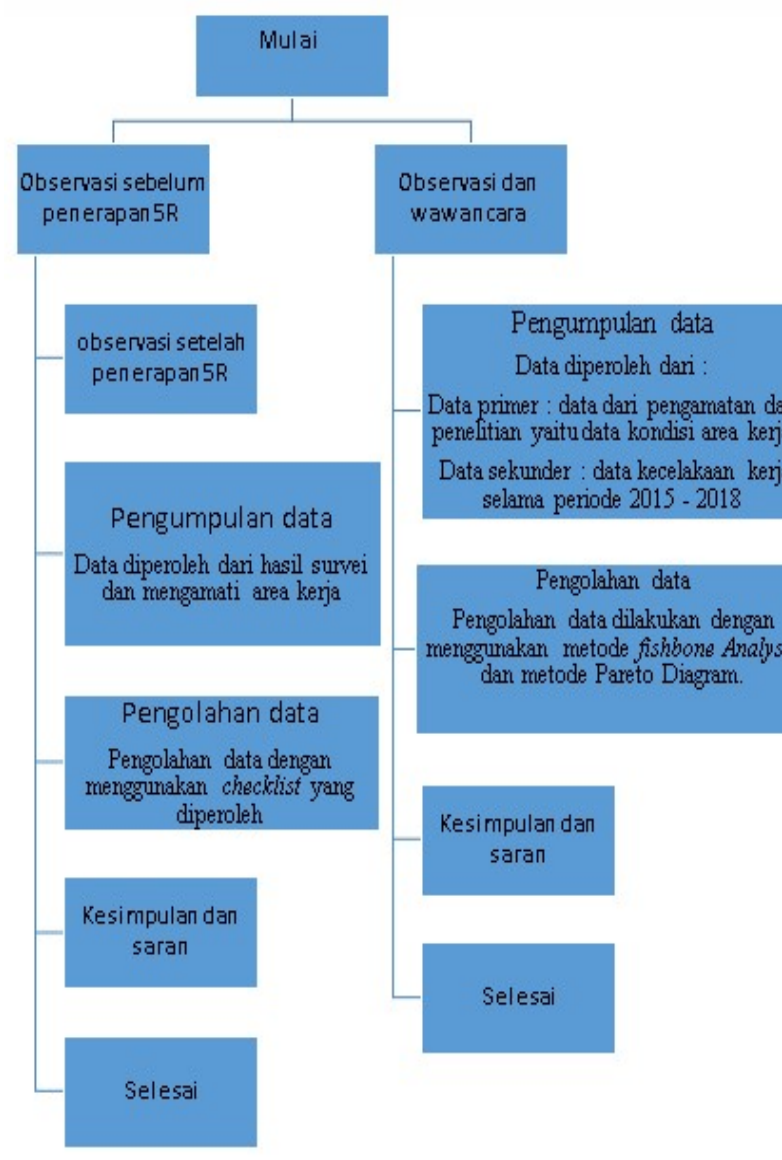

\section{Hasil dan Pembahasan} Analisis Data

Setelah mendapatkan hasil penelitian perhitungan nilai Overall Equipment Effectiveness (OEE) pada mesin tetas Petersime dan Chickmaster, maka tahap selanjutnya menganalisis hasil dari ratarata persentase nilai OEE.

\section{Perhitungan Availability Rate}

Availability rate merupakan rasio yang menggambarkan pemanfaatan waktu yang tersedia untuk kegiatan operasi mesin. Availability rate di hitung dengan rumus (Stephens, 2004):

Berdasarkan Tabel 6 dan 7 dapat dilihat bahwa rata-rata availability rate untuk mesin tetas Petersime $(91,13 \%)$ memenuhi standar global untuk nilai availability rate yaitu sebesar $90 \%$ (hedge., dkk, 2009). Tetapi untuk mesin
Availability rate $=\frac{\text { operation time }}{\text { loading time }} \times 100 \%$

Availability rate $=\frac{\text { Loading Time-down time }}{\text { Loading Time }} \times 100 \%$

a) Mesin Tetas Petersime

Operation time $=30320-2890=27430$

Availability Rate $=27430 / 30320 \times 100 \%$ $=90,46 \%$

Tabel 6. Hasil perhitungan Availability Rate mesin Petersime

\begin{tabular}{lcccc}
\hline \multicolumn{1}{c}{ Bulan } & $\begin{array}{c}\text { Loading } \\
\text { Time } \\
\text { (menit) }\end{array}$ & $\begin{array}{c}\text { Downtime } \\
\text { (menit) }\end{array}$ & $\begin{array}{c}\text { Operation } \\
\text { Time } \\
\text { (menit) }\end{array}$ & $\begin{array}{c}\text { AR } \\
(\%)\end{array}$ \\
\hline Agustus 2018 & 30320 & 2890 & 27430 & 90,46 \\
September 2018 & 30380 & 2780 & 27600 & 90,84 \\
Oktober 2018 & 30410 & 2840 & 27570 & 90,66 \\
November 2018 & 30390 & 2798 & 27592 & 90,79 \\
Desember 2018 & 30387 & 2749 & 27638 & 90,95 \\
Januari 2019 & 30399 & 2892 & 27507 & 90,48 \\
Februari 2019 & 30387 & 2772 & 27615 & 90,87 \\
Maret 2019 & 30390 & 2832 & 27558 & 90,68 \\
April 2019 & 30397 & 2325 & 28072 & 92,35 \\
Mei 2019 & 30387 & 2426 & 27961 & 92,01 \\
Juni 2019 & 30367 & 2974 & 27393 & 90,20 \\
Juli 2019 & 30409 & 2386 & 28023 & 92,15 \\
Agustus 2019 & 30391 & 2325 & 28066 & 92,34 \\
\hline \multicolumn{5}{c}{ Rata-rata } \\
\hline
\end{tabular}

Keterangan: AR: Availability Rate

b) Mesin tetas Chickmaster

Operation time $=30477-3970=26507$

Availability Rate $=26507 / 30477 \times 100 \%$

$=86,97 \%$

Tabel 7. Hasil perhitungan Availability Rate mesin Petersime

\begin{tabular}{lcccc}
\hline \multicolumn{1}{c}{ Bulan } & $\begin{array}{c}\text { Loading } \\
\text { Time } \\
\text { (menit) }\end{array}$ & $\begin{array}{c}\text { Downtime } \\
\text { (menit) }\end{array}$ & $\begin{array}{c}\text { Operation } \\
\text { Time } \\
\text { (menit) }\end{array}$ & $\begin{array}{c}\text { AR } \\
(\%)\end{array}$ \\
\hline Agustus 2018 & 30477 & 3970 & 26507 & 86,97 \\
September 2018 & 30459 & 3890 & 26569 & 87,22 \\
Oktober 2018 & 30481 & 3087 & 27394 & 89,87 \\
November 2018 & 30498 & 3563 & 26935 & 88,31 \\
Desember 2018 & 30489 & 3254 & 27235 & 89,32 \\
Januari 2019 & 30495 & 3765 & 26730 & 87,65 \\
Februari 2019 & 30481 & 3678 & 26803 & 87,93 \\
Maret 2019 & 30499 & 3099 & 27400 & 89,83 \\
April 2019 & 30465 & 3987 & 26478 & 86,91 \\
Mei 2019 & 30475 & 3980 & 26495 & 86,94 \\
Juni 2019 & 30456 & 3876 & 26580 & 87,27 \\
Juli 2019 & 30476 & 3211 & 27265 & 89,46 \\
Agustus 2019 & 30452 & 3091 & 27361 & 89,84 \\
\hline \multicolumn{5}{c}{ Rata-rata } \\
\hline
\end{tabular}

tetas Chickmaster belum memenuhi standar $(88,27 \%)$

\section{Perhitungan Performance rate}

Performance rate adalah rasio yang menggambarkan kemampuan suatu 
mesin atau peralatan dalam menghasilkan produk atau barang. Performance rate dihitung dengan rumus (Stephens, 2004).

a) Mesin tetas Petersime:

Performance rate $=\frac{94656 \times 0,3203}{2890} \times 100 \%=10,49 \%$

Tabel 8. Hasil perhitungan Performance Rate (PR) mesin Petersime

\begin{tabular}{lcccc}
\hline \multicolumn{1}{c}{ Bulan } & $\begin{array}{c}\text { Processed } \\
\text { amount } \\
\text { (butir) }\end{array}$ & $\begin{array}{c}\text { Loading } \\
\text { Time } \\
\text { (menit) }\end{array}$ & $\begin{array}{c}\text { Downtime } \\
\text { (menit) }\end{array}$ & $\begin{array}{c}\text { PR } \\
\text { (\%) }\end{array}$ \\
\hline Agustus 2018 & 94656 & 30320 & 2890 & 10,49 \\
September 2018 & 94670 & 30380 & 2780 & 10,92 \\
Oktober 2018 & 94701 & 30410 & 2840 & 10,70 \\
November 2018 & 94727 & 30390 & 2798 & 10,88 \\
Desember 2018 & 94011 & 30387 & 2749 & 11,05 \\
Januari 2019 & 93971 & 30399 & 2892 & 10,50 \\
Februari 2019 & 93997 & 30387 & 2772 & 10,95 \\
Maret 2019 & 94000 & 30390 & 2832 & 10,72 \\
April 2019 & 93801 & 30397 & 2325 & 13,07 \\
Mei 2019 & 93891 & 30387 & 2426 & 12,52 \\
Juni 2019 & 94015 & 30367 & 2974 & 10,21 \\
Juli 2019 & 94062 & 30409 & 2386 & 12,74 \\
Agustus 2019 & 93914 & 30391 & 2325 & 13,07 \\
\hline
\end{tabular}

a) Mesin tetas Chickmaster

Performance rate $=\frac{93711 \times 0,3252}{3970} 100 \%=7,67 \%$

Tabel 9. Hasil perhitungan Performance Rate (PR) mesin Chickmaster

\begin{tabular}{lcccc}
\hline \multicolumn{1}{c}{ Bulan } & $\begin{array}{c}\text { Processed } \\
\text { amount } \\
\text { (butir) }\end{array}$ & $\begin{array}{c}\text { Loading } \\
\text { Time } \\
\text { (menit) }\end{array}$ & $\begin{array}{c}\text { Downtime } \\
\text { (menit) }\end{array}$ & $\begin{array}{c}\text { PR } \\
(\%)\end{array}$ \\
\hline Agustus 2018 & 93711 & 30477 & 3970 & 7,67 \\
September 2018 & 93799 & 30459 & 3890 & 7,50 \\
Oktober 2018 & 93617 & 30481 & 3087 & 9,85 \\
November 2018 & 94013 & 30498 & 3563 & 8,55 \\
Desember 2018 & 93711 & 30489 & 3254 & 9,36 \\
Januari 2019 & 93119 & 30495 & 3765 & 8,09 \\
Februari 2019 & 93123 & 30481 & 3678 & 8,28 \\
Maret 2019 & 93670 & 30499 & 3099 & 9,84 \\
April 2019 & 93511 & 30465 & 3987 & 7,63 \\
Mei 2019 & 93711 & 30475 & 3980 & 7,65 \\
Juni 2019 & 93816 & 30456 & 3876 & 7,85 \\
Juli 2019 & 93847 & 30476 & 3211 & 9,48 \\
Agustus 2019 & 93701 & 30452 & 3091 & 9,84 \\
\hline & \multicolumn{5}{c}{ Rata-rata } & 8,59
\end{tabular}

Berdasarkan tabel 8 dan 9 dapat dilihat bahwa rata-rata performance rate dari kedua mesin tetas Petersime dan Chickmaster masing-masing belum

memenuhi standar global untuk nilai performance rate sebesar 90\% (Hegde. Dkk, 2009).

\section{Perhitungan Rate Of Quality}

Rate of quality adalah rasio mesin dalam menghasilkan suatu produk sesuai dengan standar yang telah di tetapkan. Rate of quality di hitung dengan rumus (Stephens, 2004):

$$
\text { Rate of Quality product }=\frac{\text { Processed amount }- \text { Def ect amount }}{\text { Procassed amount }} \times 100 \%
$$

a. Mesin tetas Petersime:

$$
\begin{aligned}
\text { Rate of Quality product } & =\frac{94656-410}{94656} \times 100 \% \\
& =99,56 \%
\end{aligned}
$$

Tabel 10. Hasil perhitungan Rate of Quality Mesin Petersime 


\begin{tabular}{lccc}
\hline Bulan & $\begin{array}{c}\text { Processed } \\
\text { amount } \\
\text { (butir) }\end{array}$ & $\begin{array}{c}\text { Defect } \\
\text { amount } \\
\text { (butir) }\end{array}$ & $\begin{array}{c}\text { RQ } \\
(\%)\end{array}$ \\
\hline Agustus 2018 & 94656 & 410 & 99,56 \\
September 2018 & 94670 & 419 & 99,59 \\
Oktober 2018 & 94701 & 419 & 99,55 \\
November 2018 & 94727 & 427 & 99,54 \\
Desember 2018 & 94011 & 417 & 99,55 \\
Januari 2019 & 93971 & 451 & 99,52 \\
Februari 2019 & 93997 & 424 & 99,54 \\
Maret 2019 & 94000 & 432 & 99,54 \\
April 2019 & 93801 & 439 & 99,53 \\
Mei 2019 & 93891 & 443 & 99,52 \\
Juni 2019 & 94015 & 457 & 99,51 \\
Juli 2019 & 94062 & 448 & 99,52 \\
Agustus 2019 & 93914 & 437 & 99,53 \\
\hline
\end{tabular}

Keterangan: RQ: Rate of Quality

b. Mesin tetas Chickmaster:

Rate of Quality product $=\frac{\text { processed amount }- \text { Def act amount }}{\text { processed amount }} \times 1 \mathrm{C}$

$$
\begin{aligned}
\text { Rate of Quality product } & =\frac{93711-473}{93711} \times 100 \% \\
& =99,49 \%
\end{aligned}
$$

Tabel 11. Hasil perhitungan Rate of Quality Mesin Chickmaster

\begin{tabular}{lccc}
\hline \multicolumn{1}{c}{ Bulan } & $\begin{array}{c}\text { Processed } \\
\text { amount } \\
\text { (butir) }\end{array}$ & $\begin{array}{c}\text { Defect amount } \\
\text { (butir) }\end{array}$ & $\begin{array}{c}\mathrm{RQ} \\
(\%)\end{array}$ \\
\hline Agustus 2018 & 93711 & 473 & 99,49 \\
September 2018 & 93799 & 462 & 99,50 \\
Oktober 2018 & 93617 & 481 & 99,54 \\
November 2018 & 94013 & 479 & 99,49 \\
Desember 2018 & 93711 & 497 & 99,55 \\
Januari 2019 & 93119 & 489 & 99,47 \\
Februari 2019 & 93123 & 499 & 99,46 \\
Maret 2019 & 93670 & 491 & 99,12 \\
April 2019 & 93511 & 483 & 99,48 \\
Mei 2019 & 93711 & 494 & 99,47 \\
Juni 2019 & 93816 & 509 & 99,45 \\
Juli 2019 & 93847 & 482 & 99,48 \\
Agustus 2019 & 93701 & 507 & 99,46 \\
\hline & Rata-rata & & 99,45 \\
\hline
\end{tabular}

Keterangan: RQ: Rate of Quality

Berdasarkan tabel 10 dan 11 dapat dilihat bahwa nilai RQ dari mesin Petersime dan Chickmaster sudah memenuhi standar rate of quality $(99,53 \%$ dan 99,45\%). dimana Standar untuk nilai Rate of Quality sebesar 99\% (Hegde.,dkk, 2009).

\section{Perhitungan OEE}

Tahap ini menghitung nilai Overall Equipment Effectiveness dari mesin Petersime dan Chickmaster, untuk mengetahui efektivitas secara total dari kinerja suatu peralatan dalam melakukan suatu pekerjaan yang sudah direncanakan, diukur dari data actual terkait dengan availability rate, performance rate, dan rate of quality yang masing-masing dapat dilihat pada tabel dibawah ini. OEE dihitung dengan rumus (Stephens, 2004):

$\mathrm{OEE}=\mathrm{AR} \times \mathrm{PR} \times \mathrm{RQ}$

a). Mesin Petersime OEE $=90,43 \%$

X 10,49\% X 99,56\% $=94,47 \%$

$$
\text { Perhitungan Overall }
$$

Equipment Effectiveness mesin Petersime:

Tabel 12. Hasil Perhitungan OEE Mesin Petersime

\begin{tabular}{lcccc}
\hline \multicolumn{1}{c}{ Bulan } & $A R(\%)$ & $P R(\%)$ & $R Q(\%)$ & OEE (\%) \\
\hline Agustus 2018 & 90,46 & 10,49 & 99,56 & 94,47 \\
September 2018 & 90,84 & 10,92 & 99,59 & 98,79 \\
Oktober 2018 & 90,66 & 10,70 & 99,55 & 96,56 \\
November 2018 & 90,79 & 10,88 & 99,54 & 98,32 \\
Desember 2018 & 90,95 & 11,05 & 99,55 & 99,97 \\
Januari 2019 & 90,48 & 10,50 & 99,52 & 94,54 \\
Februari 2019 & 90,87 & 10,95 & 99,54 & 99,04 \\
Maret 2019 & 90,68 & 10,72 & 99,54 & 96,76 \\
April 2019 & 92,35 & 13,07 & 99,53 & 99,98 \\
Mei 2019 & 92,01 & 12,52 & 99,52 & 99,99 \\
Juni 2019 & 90,20 & 10,21 & 99,51 & 91,64 \\
Juli 2019 & 92,15 & 12,74 & 99,52 & 99,97 \\
Agustus 2019 & 92,34 & 13,07 & 99,53 & 99,98 \\
\hline \multicolumn{5}{r}{ Keterangan: AR: Availabily Rate } \\
& PR: Pefformance Rate & OEE: Overall Equipment Effectivenes
\end{tabular}

b). Mesin Chickmaster OEE $=86,97 \% \mathrm{X}$ $7,75 \%$ X 99, $49 \%=67,05 \%$

Tabel 13. Hasil Perhitungan OEE Mesin Chickmaster

\begin{tabular}{lcccc}
\hline \multicolumn{1}{c}{ Bulan } & $A R(\%)$ & $P R(\%)$ & $R Q(\%)$ & OEE $(\%)$ \\
\hline Agustus 2018 & 86,97 & 7,67 & 99,49 & 66,36 \\
September 2018 & 87,22 & 7,50 & 99,50 & 65,08 \\
Oktober 2018 & 89,87 & 9,85 & 99,54 & 88,38 \\
November 2018 & 88,31 & 8,55 & 99,49 & 75,11 \\
Desember 2018 & 89,32 & 9,36 & 99,55 & 83,22 \\
Januari 2019 & 87,65 & 8,09 & 99,47 & 70,53 \\
Februari 2019 & 87,93 & 8,28 & 99,46 & 72,41 \\
Maret 2019 & 89,83 & 9,84 & 99,12 & 87,61 \\
April 2019 & 86,91 & 7,63 & 99,48 & 65,96 \\
Mei 2019 & 86,94 & 7,65 & 99,47 & 66,15 \\
Juni 2019 & 87,27 & 7,85 & 99,45 & 68,13 \\
Juli 2019 & 89,46 & 9,48 & 99,48 & 84,36 \\
Agustus 2019 & 89,84 & 9,84 & 99,46 & 87,92 \\
\hline
\end{tabular}


Pada tabel 12 dan 13 di dapat diketahui besar nilai rata-rata OEE pada mesin Petersime $97,92 \%$ dan pada mesin Chickmaster $75,51 \%$, nilai pada mesin Petersime sudah memenuhi standar nilai OEE yaitu $85 \%$, sedangkan pada mesin Chickmaster belum masuk nilai standar OEE.

\section{Analisis Six Big Losses}

OEE menyoroti 6 kerugian utama (Six Big Losses ) penyebab peralatan produksi tidak beroprasi secara normal. Dari 6 kerugian utama dikelompokkan menjadi 3 yaitu downtime losses, speed losses, quality losses.

1. Downtime Losses

Downtime adalah waktu yang terbuang, dimana produksi tidak berjalan yang biasanya diakibatkan oleh kerusakan mesin. Downtime terdiri dari 2 macam kerugian yaitu

a.Breakdown Losses yaitu kerusakan mesin atau peralatan secara tiba-tiba, tentunta kerusakan yang terjadi secara tiba-tiba ini dapat menimbulkan kerugian, dimana mesin tidak beroprasi menghasilkan output yang diingginkan. Berikut perhitungan breakdown losses dengan rumus (Stephens,2004):

$\frac{\text { Downtime }}{\text { Lading time }} \times 100 \%$

b. Setup and Adjusment

Losses,dikarenakan karena adanya waktu yang tercuri akibat waktu setup yang tercuri akibat waktu setup yang lama. Berikut perhitungan Setup and Adjusment Losses dengan rumus (Stephens, 2004):

$$
\frac{\text { Setup time }}{\text { Loading Time }} \times 100 \%
$$

\section{2. $\quad$ Speed Losses}

Speed losses terdiri dari 2 macam kerugian, yaitu:
a.Idling and Minor Stoppage Losses, dikarenakan mesin mengalami kemacetan maupun mesin mengalami pemberhentian sejenak. Berikut perhitungan Idling and Minor Stoppage Losses dengan rumus (Stephens, 2004):

$\frac{\text { non productive time }}{\text { Lading time }} \times 100 \%$

b.Reduced Speed Losses, dimana kerugian ini disebabkan karena mesin atau peralatan mengalami penurunan kecepatan. Berikut perhitungan Reduced Speed Losses dengan rumus (Spephens, 2004):

$\frac{\text { Operating time-(ideal cycle time } \times \text { Processed amount }}{\text { Loading time }} \times 100 \%$

\section{Quality Losses}

Quality Losses adalah suatu keadaan dimana produk yang di hasilkan tidak sesuai dengan spesifikasi yang telah di tetapkan. Quality Losses terdiri dari 2 macam, antara lain:

a.Process Defect, kerugian dikarenakan produk hasil produksi dimana produksi dimana produk tersebut memiliki kekurangan (cacat) setelah keluar dari proses produksi.

Ialeal cycle time $x$ befect amount Ladiing time $\times 100 \%$

b.Reduced Yield Losses, kerugian yang diakibatkan suatu keadaan di mana produk yang di hasilkan tidak sesuai standar, karena terjadi perbedaan kualitas antara waktu mesin pertama kali di nyalakan dengan pada saat mesin tersebut sudah stabil beroprasi.

Ideal cycle time $x$ reject

Loading time

Tabel 14. Hasil Perhitungan Time Losses mesin tetas Petersime 


\begin{tabular}{lcccccc}
\hline \multicolumn{1}{c}{ Bulan } & $\begin{array}{c}\text { Breakd } \\
\text { own } \\
\text { Lossed } \\
\text { (menit) }\end{array}$ & $\begin{array}{c}\text { Setup } \\
\text { And } \\
\text { Adjustme } \\
\text { nt Losses } \\
\text { (menit) }\end{array}$ & $\begin{array}{c}\text { Idling And } \\
\text { Minor } \\
\text { Stoppages } \\
\text { Losses } \\
\text { (menit) }\end{array}$ & $\begin{array}{c}\text { Speed } \\
\text { Losses } \\
\text { (menit) }\end{array}$ & $\begin{array}{c}\text { Qualiy } \\
\text { Defect } \\
\text { (menit) }\end{array}$ & $\begin{array}{c}\text { Yield } \\
\text { Losses } \\
\text { (menit) }\end{array}$ \\
\hline Agustus 2018 & 2890 & 1385 & 0,610 & 39,0831 & 0,222 & 0 \\
September 2018 & 2780 & 1418 & 0,631 & 39,5885 & 0,226 & 0 \\
Oktober 2018 & 2840 & 1479 & 0,618 & 39,4343 & 0,226 & 0 \\
November 2018 & 2798 & 1454 & 0,665 & 39,5195 & 0,230 & 0 \\
Desember 2018 & 2749 & 1392 & 0,688 & 39,9291 & 0,225 & 0 \\
Januari 2019 & 2892 & 1486 & 0,557 & 39,6361 & 0,292 & 0 \\
Februari 2019 & 2772 & 1454 & 0,598 & 39,9940 & 0,228 & 0 \\
Maret 2019 & 2832 & 1411 & 0,533 & 39,7992 & 0,233 & 0 \\
April 2019 & 2325 & 1421 & 0,565 & 41,5896 & 0,237 & 0 \\
Mei 2019 & 2426 & 1438 & 0,651 & 41,1886 & 0,239 & 0 \\
Juni 2019 & 2974 & 1445 & 0,615 & 39,2794 & 0,247 & 0 \\
Juli 2019 & 2386 & 1450 & 0,620 & 41,8626 & 0,241 & 0 \\
Agustus 2019 & 2325 & 1470 & 0,651 & 41,5188 & 0,187 & 0 \\
\hline \multicolumn{1}{c}{ Total } & 34989 & 18703 & 8,002 & 522,4228 & 3,033 & 0 \\
\hline
\end{tabular}

Tabel 15. Persentase Kumulatif Six Big Losses mesin tetas Petersime

\begin{tabular}{cccc}
\hline Six Big Losses & Total Time Losses & Persentase (\%) & $\begin{array}{c}\text { Persentase } \\
\text { Kumulatif(\%) }\end{array}$ \\
Breakdown Losses & 34989 & 65 & 35 \\
Setup And & 18703 & 34 & 23 \\
Adiustmen Losses & & & \\
Idling And Minor & 8,002 & 14 & 0 \\
Stoppages Losses & & & \\
Speed Losses & 522,4228 & 9 & 1 \\
Qualiny Defect & 3,033 & 5 & 0 \\
Yield Losses & 0 & 0 & 100 \\
Total & 54225 & 127 & 159 \\
& & &
\end{tabular}

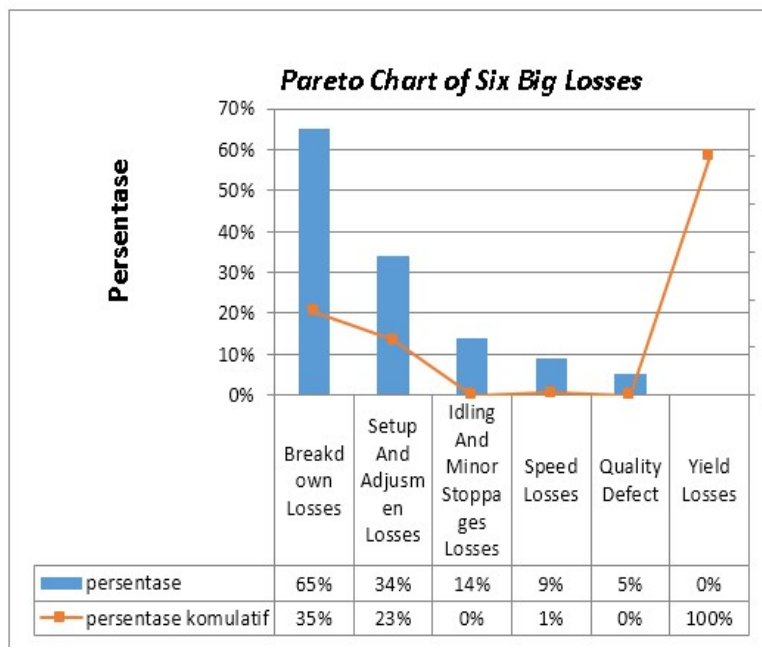

\section{Gambar 3. Diagram Pareto Six Big}

Losses Mesin Tetas Petersime

Tabel 16. Hasil perhitungan Time Losses mesin tetas Chickmaster

\begin{tabular}{lcccccc}
\hline \multicolumn{1}{c}{ Bulan } & $\begin{array}{c}\text { Breakdown } \\
\text { Lossed } \\
\text { (menit) }\end{array}$ & $\begin{array}{c}\text { Setup } \\
\text { And } \\
\text { Adjust } \\
\text { ment } \\
\text { Losses } \\
\text { (menit) }\end{array}$ & $\begin{array}{c}\text { Idling And } \\
\text { Minor } \\
\text { Stoppages } \\
\text { Losses } \\
\text { (menit) }\end{array}$ & $\begin{array}{c}\text { Speed } \\
\text { Losses } \\
\text { (menit) }\end{array}$ & $\begin{array}{c}\text { Qualiy } \\
\text { Defect } \\
\text { (menit) }\end{array}$ & $\begin{array}{c}\text { Yield } \\
\text { Losses } \\
\text { (menit) }\end{array}$ \\
\hline Agustus 2018 & 3970 & 1499 & 0,636 & 36,394 & 0,255 & 0 \\
September 2018 & 3890 & 1506 & 0,705 & 36,573 & 0,249 & 0 \\
Oktober 2018 & 3087 & 1482 & 0,688 & 39,372 & 0,259 & 0 \\
November 2018 & 3563 & 1498 & 0,701 & 37,609 & 0,258 & 0 \\
Desember 2018 & 3254 & 1508 & 0,718 & 38,768 & 0,268 & 0 \\
Januari 2019 & 3765 & 1505 & 0,731 & 37,422 & 0,263 & 0 \\
Februari 2019 & 3678 & 1482 & 0,708 & 37,679 & 0,269 & 0 \\
Maret 2019 & 3099 & 1498 & 0,649 & 39,319 & 0,264 & 0 \\
April 2019 & 3987 & 1513 & 0,669 & 36,422 & 0,260 & 0 \\
Mei 2019 & 3980 & 1509 & 0,685 & 36,357 & 0,266 & 0 \\
Juni 2019 & 3876 & 1497 & 0,646 & 36,603 & 0,274 & 0 \\
Juli 2019 & 3211 & 1489 & 0,675 & 38,810 & 0,260 & 0 \\
Agustus 2019 & 3091 & 1517 & 0,692 & 39,235 & 0,273 & 0 \\
\hline \multicolumn{1}{c}{ Total } & 46451 & 19503 & $\mathbf{8 , 9 0 3}$ & 490,563 & 3,418 & 0 \\
\hline \multicolumn{1}{c}{} & & & & & & \\
\hline
\end{tabular}

Tabel 17. Persentase Kumulatif Six Big Losses

\begin{tabular}{cccc}
\multicolumn{4}{c}{ mesin tetas Chickmaster } \\
\hline Six Big Losses & Total Time Losses & Persentase (\%) & $\begin{array}{c}\text { Persentase } \\
\text { Kumulatif (\%) }\end{array}$ \\
\hline $\begin{array}{c}\text { Breakdown Losses } \\
\text { Setup And }\end{array}$ & 46451 & 69 & 34 \\
Adjustmen Losses & 19503 & 29 & 23 \\
Idling And Minor & 8,903 & 13 & 0 \\
Stoppages Losses & & & \\
Speed Losses & 490,563 & 7 & 1 \\
Qualiy Defect & 3,418 & 5 & 0 \\
Yield Losses & 0 & 0 & 100 \\
\hline Total & 66456 & 123 & 158 \\
\hline
\end{tabular}

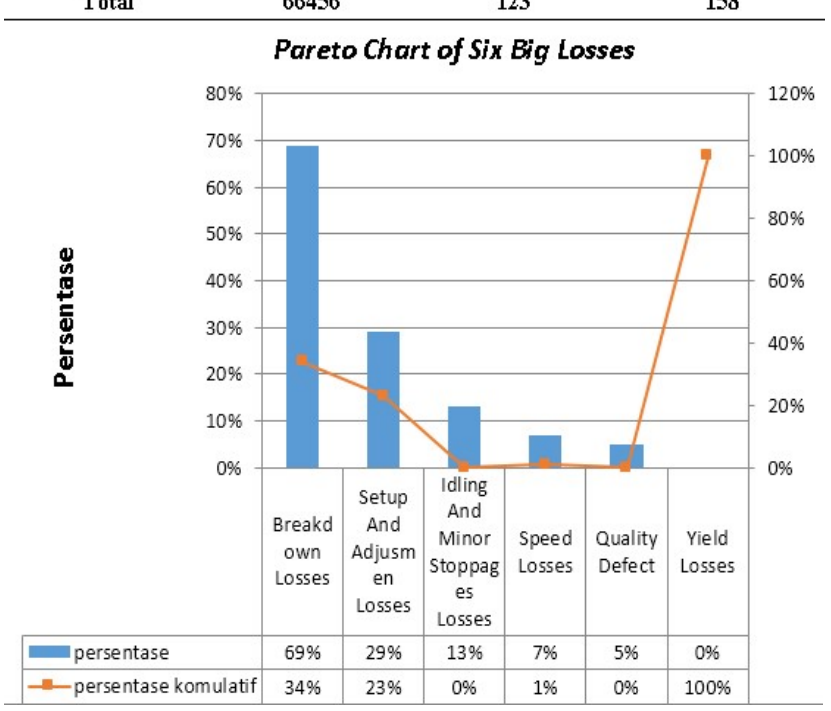

Gambar 4. Diagram Pareto Six Big

Losses Mesin Tetas Chickmaster

Setelah mengetahui penyebab permasalahan dari mesin Petersime dan Chickmaster yang dilihat dari hasil persentase dan persentase komulatif dan diagram pareto sebelumnya, dapat dilihat pengaruh terbesar dalam faktor six big losses yaitu pada Break Down Losses pada mesin Petersime $65 \%$ dan pada mesin Chickmaster 69\% dengan persentase komulatif kedua mesin masih 
dibawah $80 \%$, oleh karena itu, faktor Break Down Losses inilah yang selanjutnya akan dilakukan analisis dengan menggunakan diagram sebab akikat (fishbone diagram) untuk mengetahui apa saja penyebab-penyebab yang memengaruhi nilai break down losses pada mesin.

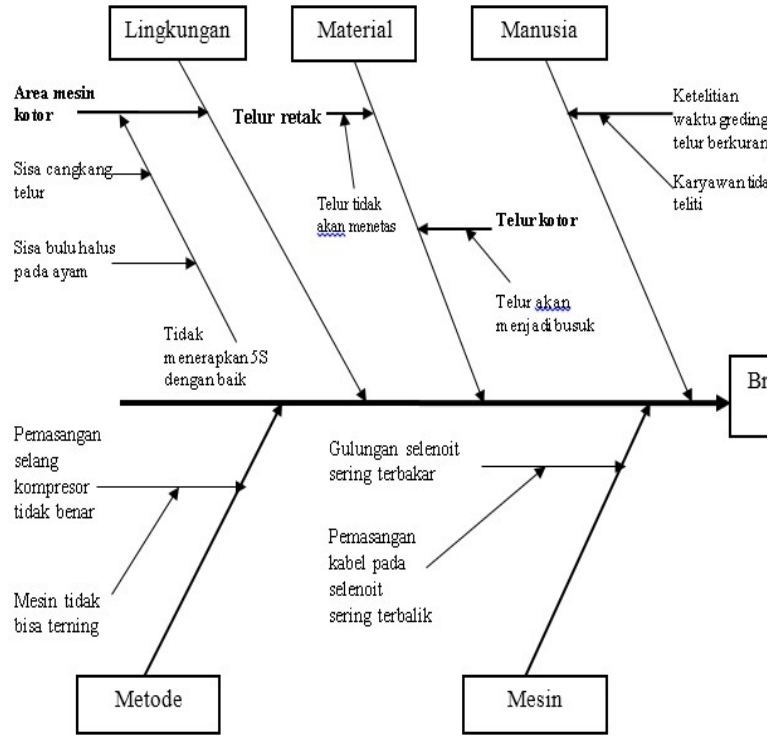

Gambar 5. Diagram Fishbone Break Down Losses

\section{Usulan Perbaikan Dengan Metode $5 \mathrm{~W}+1 \mathrm{H}$}

Pada Diagram Pareto mengenai Six big losses telah diperoleh hasil yang memberikan pengaruh terbesar dalam rendahnya efektivitas mesin yaitu pada reduced speed loss dan kemudian menganalisis penyebab-penyebab reduced speed loss menggunakan fishbone diagram. Oleh karena itu, masalah ini harus segera diperbaiki sebagai langkah awal dalam usaha meningkatkan efektivitas mesin yaitu dengan menggunakan metode $5 \mathrm{~W}+1 \mathrm{H}$. 


\begin{tabular}{|c|c|c|c|c|c|c|c|}
\hline \multirow{4}{*}{ Faktor } & \multicolumn{2}{|r|}{ Why } & \multirow{2}{*}{$\frac{\text { What }}{\text { Apa rencana }}$} & \multirow{2}{*}{$\begin{array}{l}\text { Where } \\
\text { Dimana }\end{array}$} & \multirow{2}{*}{$\begin{array}{l}\text { When } \\
\text { Kapan }\end{array}$} & \multirow{2}{*}{$\begin{array}{r}\text { Who } \\
\text { Siapa }\end{array}$} & How \\
\hline & Penyebab & Mengapa perlu & & & & & Bagai mana cara \\
\hline & Dominan & diperbaiki & perbaikannya & perbaikan & perbaikan & PIC & perbaikannya? \\
\hline & & & & Dilakukan & dilakukan & Perbaikan & \\
\hline $\operatorname{six}$ & Break & jika tidak di & melakukan & Mesin tetas & Desember & Depertemen & Memberikan pelatihan \\
\hline Big & Down & perbaiki maka & perbaikan & jenis Petersime & 2018 & Teknik dan & terhadap operator untuk \\
\hline Losses & Losses & mesin tidak bisa & pada panel & dan Chickmaster & & Maintenance & melakukan perawatan \\
\hline & & beroperasi & mesin & & & & dengan baik. \\
\hline \multirow[t]{7}{*}{ Manusia } & Kelelahan & Untuk meningkatkan & memotivasi & operatao mesin & Desember & SV Divisi & Memberikan himbauan \\
\hline & dan & produktivitas operator & karyawan & Petersime dan & 2018 & Casting & untuk memaksimalkan \\
\hline & operator & dan memaksimalkan & dalam bekerja & Chickmaster & & & waktu istirahat dan | \\
\hline & mengalami & waktu istirahat & & & & & memberikan insentif \\
\hline & kejenuhan & operator & & & & & terhadap target yang \\
\hline & & & & & & & diberikan karvawan \\
\hline & & Why & What & Where & When & Who & How \\
\hline \multirow[t]{3}{*}{ Faktor } & Penyebab & Mengapa perlu & Apa rencana & Dimana & Kapan & Siapa & Bagai mana cara \\
\hline & Dominan & diperbaiki & perbaikannya & perbaikan & perbaikan & PIC & perbaikannya? \\
\hline & & & & Dilakukan & dilakukan & Perbaikan & \\
\hline \multirow[t]{7}{*}{ Material } & kurangnya & untuk mencegah & membuat & mesin tetas & Desember & operator & melakukan pengecekan \\
\hline & Perawatan & terjadinya kebakar & checklist/ & Petersime dan & 2018 & mesin & secara berkala dengan \\
\hline & Secara & pada gulungan & perawatan & Chickmaster & & & membuat checklist \\
\hline & Berkala & dinamo kipas & & & & & baik secara harian \\
\hline & & & & & & & Maupun mingguan \\
\hline & & & & & & & khusus untuk perawatan \\
\hline & & & & & & & Dan perbaikan mesin \\
\hline \multirow[t]{6}{*}{ Mesin } & gulungan & untuk mencegah & mencari & mesin tetas & Desember & operator & melaksanakan pelatihan \\
\hline & selenoit & terjadinya selenoit & penyebab & Peterisme dan & 2018 & mesin & untuk melakuka perawatan \\
\hline & kebakar & terbakar & gulungan & Chickmaster & & dandivisi & mandiri, mencari solusi \\
\hline & & & selenoit & & & Produksi & alternative untuk mencegah \\
\hline & & & terbakar & & & & terjadinya gulungan \\
\hline & & & & & & & selenoit terbakar \\
\hline
\end{tabular}




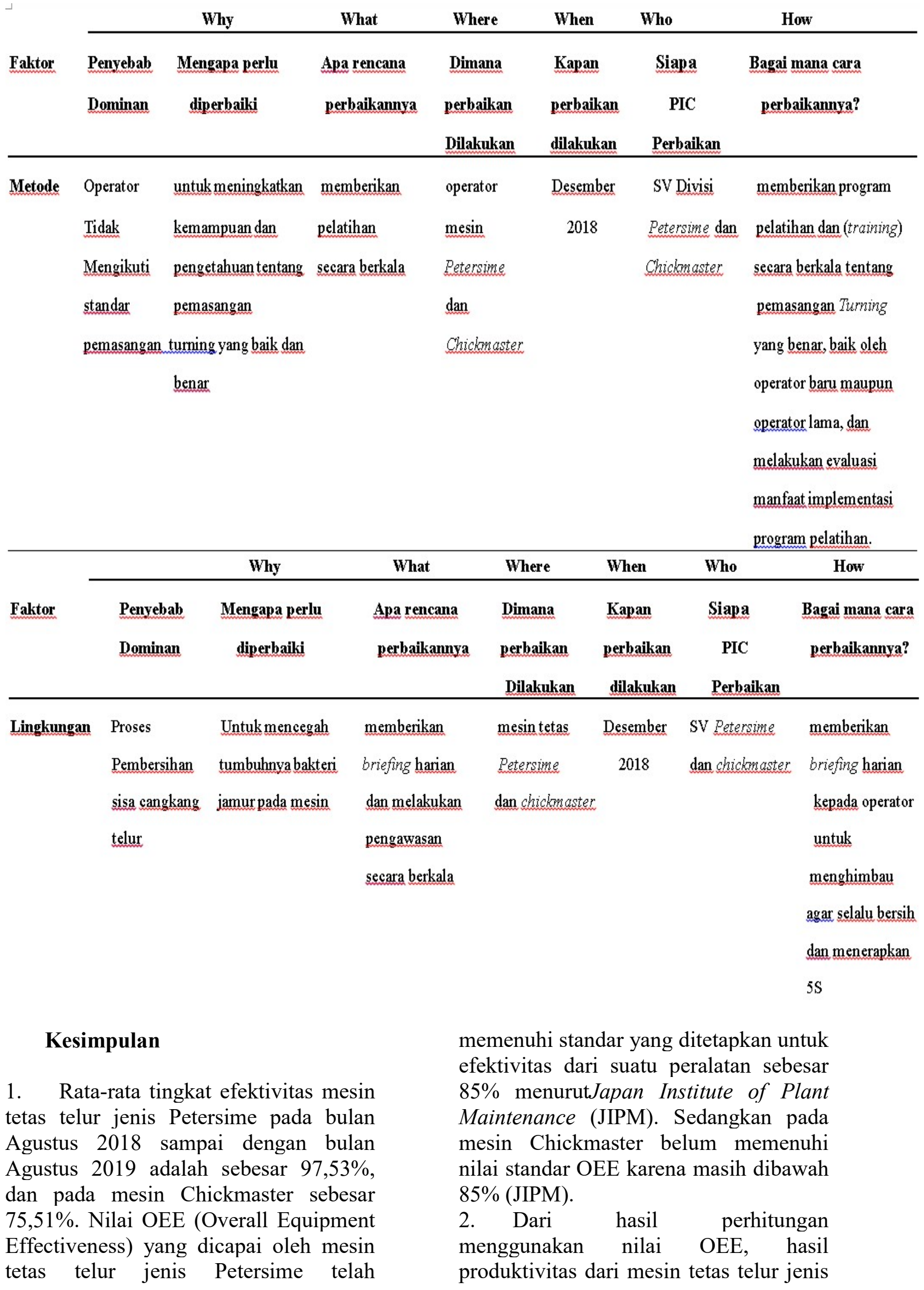


Petersime lebih baik di bandingkan jenis Chickmaster.

3. Pada analisis Six Big Losses diketahui bahwa faktor kerusakan mesin (Break Down Losses) adalah faktor yang dominan sebagai penyebab peralatan produksi tidak beroperasi secara normal baik pada mesin tetas Petersime dan Chickmaster.

4. Dari analisis Fishbone dapat diketahui yang mempengaruhi Break Down Losses (kerusakan mesin) yaitu gulungan selenoit yang sering terbakar.

\section{Daftar Pustaka}

Anwar., et. Al. 2016.Analisis Overall Equipment Effectiveness (OEE) dalam Meminimalisir Six Big Losses pada Mesin Produksi di UD. Hidup Baru. Industrial Engineering Journal. Vol. 5 No. 2: 52-57.

Arifianto, A.2018.Penerapan Total

Productive Maintenance (TPM) Dengan Menggunakan Metode Overall Equipment Effectiveness.Skripsi. Fakultas Teknologi Industri Universitas Islam Indonesia, Yogyakarta.

Amin, S., \& Kholil, M. (2014).

Pengantar Tenik Industri: Graha Ilmu

Dokter Unggas. 2016.Penyimpanan

Telur. DokterUnggas.com.

Eggs And egg Products Processing. 2013.

\section{Struktur}

Telur.Amelcomel1234.blogspot.co

$\mathrm{m}$.

Iswardi, Sayuti.M, 2016. Analisis

Produktivitas Perawatan Mesin dengan Metode TPM pada mesin Mixing Section. MJ - Mechanical Science \& TechnologyVol. 4. No. 2 (2016) 10-13.

Kartasudjana. 2010. Manajemen Ternak Unggas. Jakarta.

Karim, Achmad Jamaludin Abdul. 2016.

Usulan Perbaikan Untuk Meningkatkan Efektivitas Mesin
Pressing Race Gap Steering Dengan Menggunakan OEE (Overall Equipment Effectiveness) Pada Bagian AssemblingdiPT.Suzuki Indo Mobil Motor. Jurnal Teknik Industri, Universitas Muhammadiyah Jakarta.

Mr. Petersime. 1921. Buku Panduan Mesin Tetas Petersime.

Nugroho, Asrofi. 2015. Usulan perbaikan TPM dengan Perhitungan OEE Pada Mechine Wrapping Horizontal Di PT.XYZ. Institut Sains dan Teknologi AIKamal: Jakarta.

Rinawati, D.I. dan Dewi, N. C. (2014) Analisis Penerapan Total Productive Maintenance (TPM) Menggunakan Overall Equipment Effectiveness (OEE) dan Six Big Losses pada Mesin Cavitec di PT. Essentra Surabaya. Prosiding Seminar Nasional Teknologi dan Informatika. Kudus: Universitas Muria Kudus, hal. 21-26. 